\title{
ANALISIS TRENDS TOPIK PENELITIAN MAHASISWA FAKULTAS MIPA UGM PERIODE 2016-2018
}

\section{Wiyarsih}

Pustakawan Universitas Gadjah Mada

email :wiyarsih@ugm.ac.id

\begin{abstract}
Abstrak
Fakultas MIPA UGM sampai tahun 2018 mempunyai empat departemen dan terdiri dari tujuh belas program studi. Sesuai dengan program studi (prodi) yang ada, maka bidang-bidang ilmu di Fakultas MIPA UGM terdiri dari bidang ilmu matematika, fisika, kimia, komputer, dan elektronika dan instrumentasi. Fakultas MIPA UGM berperan penting dalam mengembangkan ilmu di bidang MIPA sesuai dengan visi, misi dan tujuan FMIPA UGM. Oleh karena itu, setiap mahasiswa dengan bimbingan dosennya diharapkan dapat menemukan temuan-temuan baru dalam bidang ilmunya melalui hasil penelitian sehingga dapat mengembangkan ilmu tersebut. Tujuan kajian ini adalah membuat visualisasi grafik trends topik penelitian dan menganalisis trends topik penelitian mahasiswa Fakultas MIPA UGM periode tahun 2016-2018. Jenis penelitian ini merupakan penelitian deskriptif dengan pendekatan kuantitatif. Tempatnya di Perpustakaan Fakultas MIPA UGM. Populasinya adalah semua koleksi skripsi, tesis, dan disertasi Perpustakaan Fakultas MIPA tahun 2016-2018. Populasi ini sekaligus menjadi sampel penelitian yang berjumlah 3.111 judul hasil penelitian. Pengumpulan data menggunakan metode dokumentasi dan observasi. Pengolahan data menggunakan aplikasi Microsoft Power Business Intelligence atau lebih dikenal Microsoft Power BI. Berdasarkan hasil pengolahan data kemudian dilakukan analisis deskriptif. Berdasarkan lima kategori yaitu jenis koleksi, jenjang studi, departemen, program studi, dan tahun terbit, jumlah topik yang paling banyak diteliti atau yang paling trends adalah topik adsorpsi dari bidang ilmu kimia. Trend topik berdasarkan kategori pembimbing yang terbanyak adalah topik tentang katalisis (bidang ilmu kimia), kimia komputasi (bidang ilmu kimia), dan komputerisasi proses kontrol (bidang ilmu elektronika dan instrumentasi).
\end{abstract}

\author{
Kata kunci: \\ Analisis trends; \\ Topik penelitian; \\ IImu MIPA
}

\section{A. PENDAHULUAN}

Ilmu-ilmu Matematika dan Ilmu Pengetahuan Alam (MIPA) berperan penting dalam pengembangan Ilmu Pengetahuan dan Teknologi (IPTEK) dan kemajuan suatu bangsa termasuk bangsa Indonesia. Oleh karena itu, diperlukan Sumber Daya Manusia (SDM) yang menguasai ilmu-ilmu MIPA baik ilmu murni maupun ilmu terapan, misalnya ilmu fisika, kimia, dan matematika, komputer, dan elektronika. IImu-ilmu tersebut akan berkembang terutama dari hasil-hasil penelitian mahasiswa baik program sarjana, magister, maupun doktor sebagai karya akhir mahasiswa.
Fakultas MIPA UGM mempunyai 4 Departemen, yaitu Departemen Fisika, Departemen Kimia, Departemen Matematika, dan Departemen IImu Komputer dan Elektronika (DIKE). Masing-masing departemen mempunyai program baik program sarjana (S1), program magister (S2), dan program doktor (S3). Sampai tahun 2018, program sarjana di FMIPA UGM terdiri dari 7 program studi (prodi) yaitu Elektronika dan Instrumentasi (Elins), IImu Komputer, Fisika, Geofisika, Kimia, Matematika, dan Statistika. Selain itu ada International Undergraduate Program yang terdiri dari Computer Science Program dan Chemistry Program. Program magister ada 4 prodi yaitu matematika, Ilmu Fisika, Ilmu Kimia, dan 
Ilmu Komputer. Untuk Program Doktor terdiri dari 4 prodi yaitu Ilmu Fisika, Ilmu Komputer, IImu Kimia, dan Matematika. Sesuai dengan program studi yang ada, maka bidang-bidang ilmu di Fakultas MIPA UGM juga terdiri dari bidang ilmu matematika, fisika, kimia, komputer, dan elektronika dan instrumentasi (elins).

Fakultas MIPA UGM dalam menyelenggarakan pendidikan juga berperan penting dalam mengembangkan ilmu di bidang MIPA sesuai dengan visi, misi dan tujuan Fakultas MIPA UGM. Salah satu tujuan yang akan dicapai Fakultas MIPA UGM adalah penelitian berbasis ilmu MIPA yang hasilnya diakui sebagai rujukan nasional bereputasi internasional, serta mampu menjawab permasalahan di masyarakat, bangsa, dan negara. Berdasarkan tujuan tersebut, maka setiap mahasiswa diharapkan dapat menemukan temuan-temuan baru dalam bidang ilmunya melalui hasil penelitian sehingga dapat mengembangkan ilmu tersebut dan dapat bermanfaat bagi masyarakat.

Sebagai salah satu syarat kelulusan dan untuk menerapkan metode ilmiah, setiap mahasiswa diwajibkan untuk melakukan penelitian dan membuat karya tulis ilmiah berupa skripsi untuk jenjang S1, tesis untuk jenjang S2, dan disertasi untuk jenjang S3. Dalam proses awal penelitiannya setiap mahasiswa harus memilih topik atau permasalahan penelitian sesuai dengan bidang ilmunya. Bagi mahasiswa yang belum pernah melakukan kegiatan penelitian akan menemui kesulitan dalam menentukan topik atau masalah penelitiannya. Untuk itu setiap mahasiswa sebelum melaksanakan penelitian hendaknya mengetahui penelitian apa yang sudah dan belum pernah diteliti mahasiswa lain sehingga tidak terjadi duplikasi penelitian.

Perpustakaan FMIPA UGM sebagai sumber informasi bagi sivitas akademika khususnya mahasiswa FMIPA UGM, mempunyai koleksi repository yaitu skripsi, tesis, dan disertasi dalam format digital dari semua mahasiswa yang telah menyelesaikan studinya. Sampai akhir tahun 2019, koleksi repository Perpustakaan FMIPA UGM berjumlah 13.043 judul. Data koleksi tersebut merupakan kekayaan perpustakaan yang sangat berharga karena apabila diolah dengan baik dan benar maka dapat sebagai bahan pengambilan keputusan untuk kepentingan pemustaka. Salah satunya adalah untuk mengetahui trend topik penelitian mahasiswa. Salah satu aplikasi yang dapat digunakan untuk mengolah data tersebut adalah Microsoft Power Business Intelligence atau lebih dikenal dengan Microsoft Power Bl. Untuk itu dalam kajian ini akan menganalisis trends (kecenderungan) topik penelitian mahasiswa Fakultas MIPA UGM periode 2016-2018 menggunakan aplikasi Microsoft Power BI. Dari hasil kajian ini diharapkan dapat membantu dalam menentukan topik penelitian bagi para mahasiswa yang akan melakukan penelitian.

\section{B. TINJAUAN PUSTAKA DAN LANDASAN TEORITIS}

\section{Tinjauan Pustaka}

Berikut ini penelitian-penelitian terdahulu tentang tren topik penelitian yang telah dilakukan oleh peneliti sebelumnya. Penelitian Bahruni dan Fathrrahmad (2020) berjudul "Analisis Trend Topik Penelitian pada Web of Science dan SINTA untuk Penentuan Tema Tugas Akhir Mahasiswa". Peneliti melakukan penambangan data menggunakan teknologi web untuk mengumpulkan data informasi yang berasal dari Web of Science dan SINTA. Metode penelitiannya menggunakan Cross Industry Standard Process for Data Mining (CRISP-DM). Peneliti mengumpulkan data melalui daftar jurnal Web of Science dan SINTA. Untuk melacak tren topik penelitian, peneliti memilih rentang waktu dari tahun 2018 sampai dengan 2019 dan mengekspor data dari Web of Science Core Collection pada April 2019. Ada 38.162 publikasi yang berhasil diambil 
dari Web of Science kategori Ilmu Komputer dan Sistem Informasi dan 230 diambil dari website SINTA. Peneliti hanya mengambil 20 jurnal dengan $\mathrm{H}$-Index Tertinggi di Web of Science Core Collection. Pada SINTA, peneliti juga mengambil 20 jurnal dengan ranking SINTA 1 dan 2. Penelitian ini menyimpulkan bahwa tren penelitian yang paling banyak muncul adalah pembelajaran, jaringan, analisis, sistem, kontrol, data gambar, pengoptimalan, sistem, dan saraf.

Muhiddin (2018) telah meneliti tentang tren penelitian dengan judul "Analisis Tren Penelitian Skripsi Mahasiswa Program Studi Pendidikan Matematika Kelas Internasional di Universitas Negeri Makassar". Penelitian ini bertujuan untuk mengetahui bagaimana deskripsi tren penelitian skripsi mahasiswa Program Studi Pendidikan Matematika Kelas Internasional (ICP) di UNM dari sudut pandang jenis dan topik penelitian tahun 2015, 2016, dan 2017. Penelitian ini merupakan jenis penelitian gabungan model sequential explanatory (kuantitatif-kualitatif). Pada fase pertama, data kuantitatif diambil dari dokumen skripsi mahasiswa ICP yang diserahkan pada Perpustakaan Jurusan Matematika UNM. Data tersebut dianalisis menurut model Miles dan Huberman. Berdasarkan analisis tersebut ditemukan bahwa topik-topik penelitian secara keseluruhan (264 topik) dapat dikelompokkan dalam 3 kategori, yaitu 1) topik penelitian yang terkait aspek afektif (12\%), di mana efikasi diri, kepercayaan diri, kecemasan, motivasi, dan minat belajar menjadi tren pada tahun 2016; 2) aspek kognitif (45\%), di mana hasil, prestasi, dan kualitas belajar merupakan tren penelitian di setiap tahun dan cenderung menurun; 3 ) aspek pedagogi (39\%) di mana model pembelajaran (kooperatif) merupakan tren di setiap tahun dan cenderung menurun. Jenis penelitian secara keseluruhan (dari 103 penelitian), dikelompokkan menjadi 3 kategori, yaitu 1) jenis penelitian kuantitatif (72\%), dimana kuasi eksperimen menempati posisi tertinggi
(42\%), diikuti pre eksperimen (36\%), kemudian ex post facto $(20 \%)$, dan korelasional $(1 \%) ; 2$ ) jenis penelitian kualitatif (26\%), di mana sebagian besar adalah kualitatif deskriptif (93\%), sisanya (7\%) adalah korelasional dan studi kasus; 3) jenis penelitian gabungan (2\%). Jenis penelitian kuantitatif terus mengalami penurunan selama 3 tahun terakhir. Sebaliknya untuk penelitian kualitatif justru mengalami peningkatan. Untuk mengetahui penyebab tren penggunaan jenis penelitian oleh mahasiswa, maka penelitian ini dilanjutkan ke fase kedua melalui wawancara dengan teknik pemilihan responden secara stratified purposeful sampling. Berdasarkan hasil analisis wawancara diketahui bahwa mahasiswa beralih menggunakan jenis penelitian kualitatif karena rasa jenuh mahasiswa melihat penelitian-penelitian sebelumnya yang didominasi oleh jenis penelitian kuantitatif; kedua karena adanya dorongan oleh dosen agar mahasiswa memberanikan diri mencoba jenis penelitian kualitatif, dan terakhir, karena adanya perubahan kurikulum mata kuliah metode penelitian kualitatif dari "pilihan" menjadi "wajib".

Penelitian Dwiyantoro (2020) berjudul "Tren Topik Penelitian Jurnal Terakreditasi Peringkat Sinta 2 Bidang Ilmu Perpustakaan dan Informasi di Indonesia Periode 2013-2019 (Analisis Subjek Menggunakan Pendekatan Bibliometrik Co-Word)". Penelitian ini bertujuan untuk mengetahui tren penelitian pada jurnal terakreditasi Sinta 2 bidang ilmu perpustakaan dan informasi di Indonesia periode 2013-2019. Penelitian ini menggunakan metode bibliometrik dengan pendekatan co-word. Jumlah sampel yang akan dianalisis sebanyak 400 artikel jurnal dari 4 redaksi jurnal yaitu Jurnal BACA, Jurnal BIP, Jurnal Khizanah Al Hikmah dan Jurnal JKIP periode 2013-2019. Pengelompokan kata kunci menggunakan analisis subjek. Setelah pengelompokan berdasarkan kata kunci yang sama menggunakan indeks Jaccard kemudian dianalisis menggunakan analisis subjek berdasarkan 
taksonomi Hawkins. Hasil penelitian ini menunjukkan bahwa tren penelitian jurnal akreditasi di 2 bidang ilmu perpustakaan dan informasi pada periode 2013-2019 cenderung berada pada 3 taksonomi utama yaitu Libraries and Library Services (LIS), the Information Professional, dan Information Science Research (ISR). Kesimpulan dari penelitian ini adalah bahwa tren penelitian lebih condong pada Libraries and Library Services (LIS), the Information Professional, dan Information Science Research (ISR). Kedepannya, diharapkan semua peneliti dapat mempelajari topik-topik lain sehingga perkembangan perpustakaan dan ilmu informasi dapat merata.

Sepanjang pengetahuan penulis, belum ada penelitian yang meneliti tentang tren topik penelitian mahasiswa menggunakan Microsoft Power Bl. Walaupun sama-sama tentang tren topik penelitian tetapi berbeda dalam berbagai hal seperti tempat, waktu, subjek, objek, metode, dan aplikasi yang digunakan.

\section{Kajian Teoritis}

\section{Ilmu Pengetahuan Alam (Sains)}

Menurut KBBI Online, pengertian sains (ilmu pengetahuan alam) antara lain pengetahuan sistematis tentang alam dan dunia fisik, termasuk di dalamnya, botani, fisika, kimia, geologi, zoologi, dan sebagainya; ilmu pengetahuan alam; pengetahuan sistematis yang diperoleh dari suatu observasi, penelitian, dan uji coba yang mengarah pada penentuan sifat dasar atau prinsip sesuatu yang sedang diselidiki, dipelajari, dan sebagainya (https://kbbi.web.id/sains).

Menurut Soedojo (2004, p. 33), ilmu adalah susunan sistematik berdasarkan kaidah normative tertentu terhadap keterampilan, pengertian, pemahaman, ataupun pengetahuan. Ilmu non pengetahuan ialah ilmu yang diperoleh dan dikembangkan secara sistematik terhadap kemampuan diri manusia, ataupun terhadap ide di alam pikiran manusia secara deduktif dan analitik, misalnya pencak silat, bela diri, kebatinan, dan matematika. Ilmu pengetahuan adalah ilmu yang diperoleh dan dikembangkan dengan mengolah atau memikirkan realita yang berasal dari luar diri manusia secara ilmiah, yakni dengan menerapkan metode ilmiah.

Adapun pengetahuan menurut Soedojo (2004, p. 33) ialah realita dari luar diri manusia yang lalu dimengerti, dipahami, dan diyakini kebenarannya. Pengetahuan yang ilmiah itu yang disebut ilmu pengetahuan, sedangkan pengetahuan yang non ilmiah tidak dapat diuji kebenarannya secara ilmiah, misalnya intuisi, metafisika, dan Wahyu Ilahi. Ilmu pengetahuan dikelompokkan menjadi alamiah dan sosial yakni yang berkaitan dengan kehidupan sosial manusia.

Menurut Aslichati (2011, p. 1.2) pengetahuan adalah jawaban terhadap rasa keingintahuan manusia tentang kejadian atau gejala yang terjadi di alam semesta, baik dalam bentuk fakta (abstraksi dari kejadian atau gejala), konsep (kumpulan fakta), atau prinsip (rangkaian dari konsep). Sedangkan ilmu pengetahuan atau sains (science) adalah pengetahuan yang diperoleh dengan cara tertentu, yaitu cara atau metode ilmiah.

IImu pengetahuan juga dibedakan menjadi ilmu pengetahuan murni yang berkembang berdasarkan kegairahan ingin tahu semata-mata, dan ilmu pengetahuan terapan yang berkembang karena tuntutan kebutuhan hidupdan kesejahteraan manusia. Ilmu pengetahuan murni misalnya fisika, kimia, biologi, astronomi, dan geologi. Ilmu pengetahuan terapan misalnya kedokteran, teknik, farmasi, pertanian, dan pertambangan. Dalam perkembangannya terjadi tumpang tindih antara yang murni dengan yang terapan, juga antara masing-masing cabang ilmu pengetahuan sehingga ada geofisika, kimiafisika, biokimia, astrofisika, dan sebagainya (Soedojo, 2004, p. 34). Walaupun demikian, menurut Soedojo tumbuh berkembangnya ilmu pengetahuan tersebut saling mempengaruhi. IImu 
pengetahuan murni memberikan landasan ilmiah pengembangan ilmu pengetahuan terapan, tetapi sebaliknya ilmu pengetahuan murni dirangsang pengembangannya oleh tuntutan dan tantangan yang datang dari pengembangan ilmu pengetahuan terapan.

\section{Pengertian Penelitian}

Menurut Francis Bacon dalam Soedojo bahwa pengembangan ilmu pengetahuan tidak cukup dengan perenungan filsafati betapapun dalamnya, tetapi harus dengan melakukan penelitian dalam rangka menerapkan metode ilmiah dengan metodologi tertentu. Soedojo menyatakan bahwa penelitian adalah kegiatan empirik yang terencana berdasarkan teori yang relevan, terarah ke tujuan tertentu berasaskan metode ilmiah, yaitu dalam rangka menemukan hal-hal atau teori baru (discovery), ataupun uji kebenaran atas hipotesis (verifikatif), maupun dalam upaya memperoleh dan mensintesiskan fakta-fakta empiri baru (explorative), maupun dalam usaha mengembangkan teori (development) (Soedojo, 2004, p. 69). Metode ilmiah (scientific method) menurut Aslichati (2011, p. 1.8) adalah cara atau jalan untuk mencari ilmu pengetahuan dengan mengikuti suatu struktur logis ilmiah yang dimulai dari perumusan masalah, diikuti dengan pengumpulan data yang relevan, diteruskan dengan analisis data dan interpretasi temuan, serta diakhiri dengan penarikan kesimpulan.

Menurut Soedojo (2004, p. 73), salah satu motif penelitian adalah pengembangan ilmu. Penelitian dengan motif pengembangan ilmu semata-mata pada hakekatnya adalah penelitian murni, yang boleh jadi fundamental serta bercorak explorative meskipun bukannya tanpa arah sama sekali, serta diharapkan adanya penemuan-penemuan baru. Penelitian demikian umumnya dilakukan di universitas dan lembaga penelitian murni.

\section{Karya Tulis IImiah}

Sebagai salah satu syarat kelulusan, pada umumnya mahasiswa di perguruan tinggi diwajibkan untuk melakukan penelitian dalam rangka mengembangkan ilmu pengetahuan. Dari hasil penelitian tersebut, mahasiswa menghasilkan karya tulis ilmiah. Pada program sarjana menghasilkan karya ilmiah skripsi, untuk program magister menghasilkan tesis, dan untuk program doktor menghasilkan disertasi.

Karya tulis ilmiah adalah karya tulis yang disusun berdasarkan metodeilmiah untukkelompok pembaca tertentu yang disajikan menggunakan format tertentu yang baku, seperti makalah ilmiah (scientific paper), makalah semesterial (term paper), skripsi, tesis, dan disertasi (Azhari, 2016, p. 1.2). Menurut Soedojo (2004, p. 83), karya tulis ilmiah berbeda dengan karya tulis lainnya. Karya tulis ilmiah bersifat ringkas, padat, tetapi utuh, sistematik, tidak berbasa-basi, langsung menyangkut esensinya, jelas dan tegas maknanya, serta mudah dipahami maksudnya meskipun mendasar dan mendalam uraiannya.

Berikut ini pengertian skripsi, tesis, dan disertasi menurut Azril (Azhari, 2016, p. 1.4):

\section{Skripsi}

Skripsi adalah karya tulis akademik hasil studi dan atau penelitian yang ditulis dan disusun secara sistematis berdasarkan metode ilmiah baik melalui penelitian induktif maupun deduktif yang dilakukan oleh mahasiswa di bawah pengawasan pembimbingnya. Skripsi juga merupakan salah satu syarat akademik yang harus dipenuhi untuk memperoleh gelar strata-1 (S-I) atau sarjana bagi yang menempuh jalur skripsi. Skripsi ini disusun berdasarkan hasil penelitian yang biasanya dilakukan setelah persyaratan akademik lainnya (seperti satuan kredit semester/sks) telah terpenuhi.

\section{Tesis}

Tesis adalah karya tulis akademik hasil studi dan/atau yang dilakukan secara mandiri yang ditulis dan disusun secara sistematis berdasarkan metode ilmiah, baik melalui penelitian induktif 
maupun deduktif yang dilakukan oleh mahasiswa di bawah pengawasan pembimbingnya. Tesis juga merupakan salah satu syarat akademik yang harus dipenuhi untuk mendapatkan gelar magister atau strata-2 (S-2) bagi yang menempuh jalur tesis. Tesis ini dibuat berdasarkan hasil penelitian yang cakupan penelitiannya lebih luas (bila dibandingkan dengan skripsi) dan menggunakan teori maupun konsep yang lebih komprehensif guna mendapatkan kesimpulan yang lebih umum (berlaku umum), tidak hanya berlaku pada tempat dan/atau saat tertentu saja.

\section{Disertasi}

Disertasi adalah karya tulis akademik hasil studi dan atau penelitian yang lebih mendalam yang dilakukan secara mandiri serta berisi sumbangan baru bagi perkembangan ilmu dan pengetahuan, atau penemuan jawaban baru bagi masalah-masalah yang sementara telah diketahui jawabannya atau mengajukan pertanyaan-pertanyaan baru terhadap hal-hal yang dipandang telah mapan di bidang ilmu, pengetahuan, teknologi, dan seni yang dilakukan oleh calon Doktor (S-3) di bawah pengawasan pembimbingnya.

Menurut Soedojo (2004, p. 82), skripsi adalah yang paling singkat dan kerap kali hanya merupakan rangkuman atau singkatan hasil studi pustaka, namun pembahasannya harus memiliki bobot ilmiah yaitu kritis, analitis, dan prediktif yakni daripadanya dapat dijabarkan suatu hipotesis. Tesis harus diangkat dari kegiatan penelitian sendiri dan sepenuhnya harus mencerminkan penguasaan metode ilmiah. Di samping itu, penelitian untuk tesis harus menghasilkan karya orisinil ataupun penemuan baru atau inovasi baru. Sementara itu, untuk disertasi, di samping mencerminkan penguasaan metode ilmiah juga harus mengandung pembahasan yang mendalam dan mencakup wawasan ilmiah yang luas. Selain itu, penelitian untuk disertasi harus menghasilkan penemuan baru yang fundamental, yang harus membuka cakrawala baru, bukan hanya sekedar inovasi teknis semata.

\section{Topik Penelitian}

Topik merupakan masalah atau gagasan yang akan digarap dalam karangan (Pujiono, 2013). Pada umumnya, dalam merencanakan suatu penulisan karya tulis ilmiah perlu mencakup beberapa tahapan, seperti: (1) pemilihan topik, (2) pengumpulan informasi, (3) penulisan naskah. Tahapan ini sebaiknya dilakukan secara berurutan, walaupun ada kalanya dapat dilakukan secara bersamaan (Azhari, 2016, p. 1.11).

Pemilihan topik merupakan kegiatan awal untuk melakukan penelitian. Memilih topik tidak mudah untuk dilakukan, terutama bagi peneliti pemula. Menurut Azril (Azhari, 2016, p. 1.12), pada penelitian, area topik ini disebut juga dengan cakupan masalah penelitian. Pemilihan area topik/ masalah ini merupakan langkah yang menentukan arah kegiatan selanjutnya. Topik yang digunakan oleh penulis dapat bersumber dari: (a) penulis sendiri; (b) orang lain, seperti: para ahli, dosen, atau teman Anda sendiri; (c) buku referensi dan bahan bacaan yang telah dibaca oleh penulis. Topik dapat muncul dari adanya kesenjangan (gap) antara yang seharusnya terjadi (menurut teori, konsep) dengan kenyataan yang terjadi di lapangan (praktik) berupa fakta. Dalam memilih dan menentukan topik, ada beberapa keterbatasan ( $5 \mathrm{M}$ ) yang harus disesuaikan dengan kebutuhan, yaitu:

\section{a. Minat}

Topik tulisan sebaiknya sesuai dengan minat. Topik masalah yang akan dipilih diusahakan sesuai dengan keinginan dan kebutuhan. Topik masalah yang kurang sesuai dengan minat, akan menghambat konsentrasi dan keseriusan dalam penyelesaian karya tulis tersebut.

\section{b. Mampu dilaksanakan}

Topik masalah yang dipilih harus bisa dilaksanakan dengan baik, oleh karena itu penulis harus mempunyai: 
1) Kemampuan menguasai materi dan teori/ konsep. Penulis harus mampu menguasai materi atau teori/konsep yang melatarbelakangi masalah tersebut, dan sekaligus menguasai metode pemecahannya.

2) Waktu yang cukup. Penulis harus dapat memperkirakan penggunaan waktu yang cukup dan tepat untuk menyelesaikan karya tulisnya.

3) Tenaga pelaksana yang terlatih dan cukup. Apabila diperlukan, penulis harus dapat mempersiapkan tenaga pembantu yang sudah menguasai materi dan terlatih serta jumlah yang memadai.

(4) Dana cukup tersedia. Penulis harus dapat menghimpun dana yang diperlukan.

c. Mudah dilaksanakan. Penulisan dapat dilaksanakan karena cukup faktor pendukung, seperti: (1) data cukup tersedia, (2) izin dapat diperoleh dari pihak yang berwenang.

d. Mudah dibuat masalah yang lebih luas. Topik masalah yang telah dipilih sebaiknya dapat dikembangkan lagi sehingga dapat disusun/ dibuat rancangan yang lebih kompleks untuk penulisan berikutnya.

e. Manfaat. Penulisan harus bermanfaat dan dapat digunakan hasilnya oleh orang-orang tertentu atau kelompok masyarakat dalam bidang tertentu dan khusus.

Menurut Pujiono (2013) untuk membatasi topik agar tidak terlalu luas maka hal-hal yang perlu dilakukan adalah (1) memilih salah satu topik khusus yang dikuasainya, (2) memilih satu jangka waktu tertentu untuk menyelesaikan aspek yang dipilih tersebut, (3) membatasi ruang masalah yang akan ditulis, dan (4) memilih peristiwa khusus yang berkaitan dengan topik.

\section{Microsoft Power Business Intelligence (Microsoft Power BI)}

Microsoft Power $\mathrm{BI}$ adalah software intelligence bisnis buatan Microsoft yang berguna untuk mengolah data lebih detail dan dapat menampilkan grafis lebih interaktif. Aplikasi ini dapat memvisu- alisasikan data yang telah dimasukkan dan bisa mengontrol dan memantau data dengan mudah. Microsoft Power BI mempunyai 3 konsep kerja yang sangat membantu dalam menganalisis data yaitu Dashboard, Report, dan Datasets. Dataset merupakan kumpulan data yang di-import atau dikoneksikan pada Power Bl. Report mempunyai satu atau atau lebih halaman visualisasi, bisa berupa chart atau grafik. Dashboard adalah tampilan integrasi yang menampilkan sekumpulan report dari sekumpulan dataset. Dashboard memberikan informasi data, analisa, serta memberikan gambaran dalam bentuk single visualisasi dashboard (https://www.solusi. com/mengenal-microsoft-power-bi/).

\section{METODE PENELITIAN}

Jenis penelitian ini merupakan penelitian deskriptif dengan pendekatan kuantitatif. Tempat penelitian di Perpustakaan Fakultas MIPA UGM selama 6 (enam) bulan, mulai bulan April sampai September 2019. Subjek penelitian ini adalah koleksi skripsi, tesis, dan disertasi tahun 2016-2018 di Perpustakaan Fakultas MIPA UGM. Objeknya yaitu data bibliografi laporan penelitian (skripsi, tesis, dan disertasi) Perpustakaan FMIPA UGM tahun 2016-2018 di dalam Sistem Informasi Perpustakaan (SIPUS). Populasinya adalah semua koleksi skripsi, tesis, dan disertasi Perpustakaan Fakultas MIPA tahun 2016-2018. Populasi ini sekaligus menjadi sampel penelitian (total sampling), berjumlah 3.111 judul hasil penelitian.

Pengumpulan data dalam penelitian ini menggunakan metode dokumentasi dengan tahapan sebagai berikut:

4. Melakukan download file laporan penelitian (skripsi, tesis, dan disertasi) tahun 2016-2018 melalui sistem informasi perpustakaan SIPUS

5. Melakukan eksport hasil download file laporan penelitian (skripsi, tesis, dan disertasi) ke dalam file Microsoft excel.

6. Membuat data set (melengkapi, memper- 
baiki, dan membersihkan data koleksi laporan penelitian yang meliputi judul, nama pengarang, nama pembimbing, subjek, nama departemen, nama prodi, jenis penelitian, dan tahun terbit)

Pengolahan data menggunakan aplikasi Microsoft Power BI dengan langkah sebagai berikut:

1. Mengelompokkan data berdasarkan:

a. Jenis koleksi: skripsi, tesis, dan disertasi

b. Jenjang studi: S1, S2, dan S3

c. Departemen: Fisika, Kimia, Matematika, dan Ilmu Komputer dan Elektronika

d. Program Studi: Program Sarjana terdiri dari 7 prodi, yaitu S1 Fisika, S1 Geofisika, S1 Elektronika dan Instrumentasi, S1 Ilmu Komputer, S1 Kimia, S1 Matematika, dan S1 Statistika. Program Magister terdiri dari 4 Prodi, yaitu S2 IImu Komputer, S2 IImu Fisika, S2 IImu Kimia, dan S3 Matematika. Program Doktor terdiri dari 4 Prodi yaitu S2 IImu Fisika, S3 IImu Kimia, S3 Matematika, dan S3 Ilmu Komputer

e. Tahun terbit: 2016, 2017, dan 2018

f. Pembimbing: Pembimbing pertama dan Pembimbing kedua.

2. Membuat visualisasi grafik kecenderungan topik (subjek) penelitian mahasiswa Fakultas MIPA UGM tahun 2016-2018 berdasarkan jenis penelitian, departemen, prodi, jenjang studi, nama pembimbing, dan tahun terbit.

Membuat tabulasi data (40 besar dari hasil penelitian)

Menghitung jumlah subjek penelitian sesuai kategorinya.

Mengurutkan jumlah subjek penelitian dari yang terbesar sampai yang terkecil

Membuat visualisasi grafik trends topik penelitian sesuai kategorinya.

Menghubungkan alamat grafik trends topik penelitian ke web Perpustakaan FMIPA UGM (lib. mipa.ugm.ac.id).

Penelitian ini menggunakan analisis deskriptif.
Berdasarkan hasil pengolahan data kemudian dilakukan analisis trend topik penelitian mahasiswa berdasarkan kategorinya dan dibuat kesimpulan hasil penelitian.

\section{HASIL DAN PEMBAHASAN}

Berdasarkan hasil olah data menggunakan aplikasi Microsoft Power Bl, didapatkan grafik trends topik penelitian mahasiswa berdasarkan enam kategori, yaitu berdasarkan tahun terbit, departemen, program studi, jenis penelitian, jenjang studi, dan pembimbing. Semua grafik dapat diakses secara online melalui web Perpustakaan FMIPA UGM. Garis vertikal menunjukkan topik/subjek penelitian. Garis horizontal menunjukkan jumlah topik/subjek penelitian. Topik yang paling atas menunjukkan jumlah topik yang paling banyak, dan semakin ke bawah berarti semakin sedikit jumlah topiknya. Dalam penelitian ini data diambil empat puluh besar dari seluruh topik yang diteliti. Untuk mengetahui data-data sesuai kategorinya, dengan cara mengarahkan kursor ke masing-masing warna pada grafik hasil olah data dari Microsoft Power Bl.

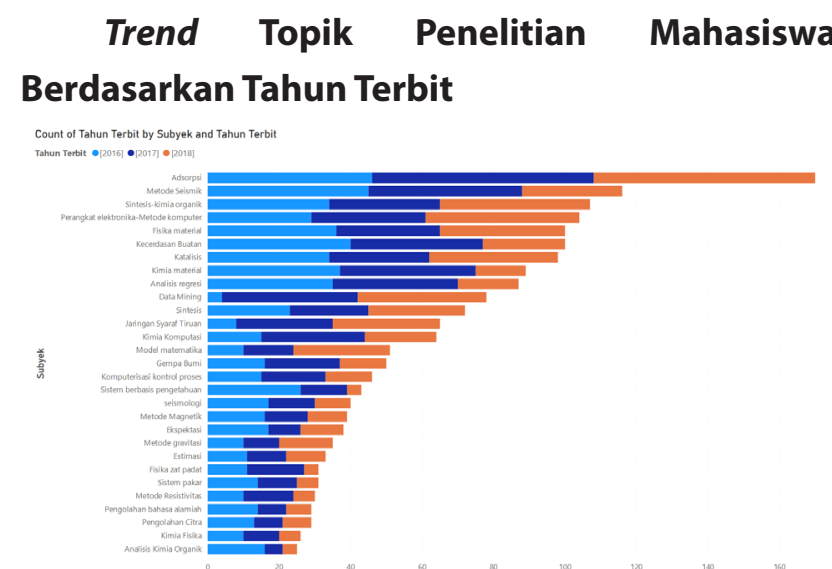

Grafik 1. Trend topik penelitian berdasarkan tahun terbit

Tabel 1. Trends topik penelitian mahasiswa berdasarkan tahun

\begin{tabular}{|c|l|l|l|}
\hline NO. & \multicolumn{1}{|c|}{2016} & \multicolumn{1}{|c|}{2017} & \multicolumn{1}{c|}{2018} \\
\hline 1 & Adsorpsi & Adsorpsi & Adsorpsi \\
\hline 2 & Metode seismik & Metode seismik & $\begin{array}{l}\text { Perangkat } \\
\text { elektronika- } \\
\text { Metode } \\
\text { komputer }\end{array}$ \\
\hline
\end{tabular}


Analisis Trends Topik Penelitian Mahasiswa Fakultas MIPA UGM periode 2016-2018

Wiyarsih

\begin{tabular}{|c|c|c|c|}
\hline NO. & 2016 & 2017 & 2018 \\
\hline 3 & $\begin{array}{l}\text { Kecerdasan } \\
\text { buatan }\end{array}$ & Katalisis & $\begin{array}{l}\text { Sintesis-Kimia } \\
\text { organik }\end{array}$ \\
\hline 4 & Kimia material & $\begin{array}{l}\text { Sistem berbasis } \\
\text { pengetahuan }\end{array}$ & Katalisis \\
\hline 5 & Fisika material & Analisis regresi & Data mining \\
\hline 6 & Analisis regresi & $\begin{array}{l}\text { Perangkat } \\
\text { elektronika- } \\
\text { Metode komputer }\end{array}$ & Fisika material \\
\hline 7 & $\begin{array}{l}\text { Sintesis-Kimia } \\
\text { organik }\end{array}$ & Kimia material & \begin{tabular}{|l} 
Jaringan syaraf \\
tiruan
\end{tabular} \\
\hline 8 & Katalisis & $\begin{array}{l}\text { Kecerdasan } \\
\text { buatan }\end{array}$ & Metode seismik \\
\hline 9 & $\begin{array}{l}\text { Perangkat } \\
\text { elektronika- } \\
\text { Metode komputer }\end{array}$ & Fisika material & Sintesis \\
\hline 10 & $\begin{array}{l}\text { Sistem berbasis } \\
\text { pengetahuan }\end{array}$ & Ekspektasi & $\begin{array}{l}\text { Model } \\
\text { matematika }\end{array}$ \\
\hline 11 & Sintesis & \begin{tabular}{|l|} 
Sintesis-Kimia \\
organik
\end{tabular} & $\begin{array}{l}\text { Kecerdasan } \\
\text { buatan }\end{array}$ \\
\hline 12 & Seismologi & Seismologi & Kimia komputasi \\
\hline 13 & Ekspektasi & Sintesis & Analisis regresi \\
\hline 14 & Gempa bumi & Metode magnetik & Metode gravitasi \\
\hline 15 & Metode magnetik & $\begin{array}{l}\text { Analisis kimia } \\
\text { organik }\end{array}$ & Kimia material \\
\hline 16 & $\begin{array}{l}\text { Analisis kimia } \\
\text { organik }\end{array}$ & Pengenalan pola & Gempa bumi \\
\hline 17 & Kimia komputasi & Gempa bumi & $\begin{array}{l}\text { Komputerisasi } \\
\text { control proses }\end{array}$ \\
\hline 18 & $\begin{array}{l}\text { Komputerisasi } \\
\text { control proses }\end{array}$ & Fisika zat padat & Ekspektasi \\
\hline 19 & Sistem pakar & Kimia komputasi & \begin{tabular}{|l} 
Metode \\
magnetik
\end{tabular} \\
\hline 20 & $\begin{array}{l}\text { Pengolahan } \\
\text { bahasa alami }\end{array}$ & $\begin{array}{l}\text { Komputerisasi } \\
\text { control proses }\end{array}$ & Estimasi \\
\hline 21 & Pengolahan citra & Sistem pakar & Seismologi \\
\hline 22 & Peramalan & Peramalan & $\begin{array}{l}\text { Jaringan } \\
\text { komputer }\end{array}$ \\
\hline 23 & Pengenalan pola & Estimasi & Analisis klaster \\
\hline 24 & Estimasi & Analisis klaster & Pengolahan citra \\
\hline 25 & Fisika zat padat & Pengolahan citra & $\begin{array}{l}\text { Pengendalian } \\
\text { kualitas }\end{array}$ \\
\hline 26 & $\begin{array}{l}\text { Pengendalian } \\
\text { kualitas }\end{array}$ & Model matematika & Fisika komputasi \\
\hline 27 & $\begin{array}{l}\text { Komunikasi } \\
\text { komputer }\end{array}$ & $\begin{array}{l}\text { Pengolahan } \\
\text { bahasa alami }\end{array}$ & $\begin{array}{l}\text { Pengolahan } \\
\text { bahasa alami }\end{array}$ \\
\hline 28 & $\begin{array}{l}\text { Model } \\
\text { matematika }\end{array}$ & Data mining & Peramalan \\
\hline 29 & Metode gravitasi & $\begin{array}{l}\text { Pengendalian } \\
\text { kualitas }\end{array}$ & Sistem pakar \\
\hline 30 & \begin{tabular}{|l} 
Metode \\
resistivitas
\end{tabular} & $\begin{array}{l}\text { Komunikasi } \\
\text { komputer }\end{array}$ & \begin{tabular}{|l|} 
Metode \\
resistivitas
\end{tabular} \\
\hline 31 & Kimia fisika & $\begin{array}{l}\text { Jaringan syaraf } \\
\text { tiruan }\end{array}$ & Kimia fisika \\
\hline 32 & $\begin{array}{l}\text { Jaringan } \\
\text { komputer }\end{array}$ & Kimia fisika & $\begin{array}{l}\text { Analisis } \\
\text { spektroskopi }\end{array}$ \\
\hline
\end{tabular}

\begin{tabular}{|c|c|c|c|}
\hline NO. & 2016 & 2017 & 2018 \\
\hline 33 & $\begin{array}{l}\text { Metode } \\
\text { elektromagnetik }\end{array}$ & \begin{tabular}{|l} 
Analisis \\
spektroskopi
\end{tabular} & $\begin{array}{l}\text { Metode } \\
\text { elektromagnetik }\end{array}$ \\
\hline 34 & $\begin{array}{l}\text { Jaringan syaraf } \\
\text { tiruan }\end{array}$ & Metode gravitasi & $\begin{array}{l}\text { Sistem berbasis } \\
\text { pengetahuan }\end{array}$ \\
\hline 35 & Fotokimia & Metode resistivitas & Fisika zat padat \\
\hline 36 & Analisis klaster & Fotokimia & $\begin{array}{l}\text { Analisis kimia } \\
\text { organik }\end{array}$ \\
\hline 37 & $\begin{array}{l}\text { Metode elemen } \\
\text { batas }\end{array}$ & Fisika komputasi & $\begin{array}{l}\text { Komunikasi } \\
\text { komputer }\end{array}$ \\
\hline 38 & $\begin{array}{l}\text { Analisis } \\
\text { spektroskopi }\end{array}$ & \begin{tabular}{|l|} 
Jaringan \\
komputer
\end{tabular} & Fotokimia \\
\hline 39 & Data mining & $\begin{array}{l}\text { Metode } \\
\text { elektromagnetik }\end{array}$ & Pengenalan pola \\
\hline 40 & Fisika komputasi & $\begin{array}{l}\text { Metode elemen } \\
\text { batas }\end{array}$ & $\begin{array}{l}\text { Metode elemen } \\
\text { batas }\end{array}$ \\
\hline
\end{tabular}

Berdasarkan grafik 1 dan tabel 1, diketahui trends topik penelitian tahun 2016, tahun 2017, dan tahun 2018 yang diambil empat puluh besar dari seluruh topik yang diteliti. Tiga besar trends topik tahun 2016 berturut-turut adalah adsorpsi dari bidang ilmu kimia, metode seismik dari bidang ilmu geofisika, dan kecerdasan buatan dari bidang ilmu komputer. Tiga besar trend topik penelitian tahun 2017 berturut-turut adalah adsorpsi, metode seismik, dan katalisis (bidang ilmu kimia). Tahun 2018, tiga besar trends topik penelitian berturut-turut adalah adsorpsi, perangkat elektronika-metode komputer (bidang ilmu elektronika dan instrumentasi), dan sintesis-kimia organik.

Berdasarkan hasil pengolahan data tersebut dapat diketahui bahwa topik yang paling trends antara tahun 2016-2018 adalah adsorpsi. Namun untuk topik-topik yang lainnya setiap tahun selalu bervariasi, berganti-ganti atau berubah-ubah trennya, dan mencakup semua bidang ilmu yang ada di Fakultas MIPA UGM. Hal ini juga menunjukkan bahwa ada perkembangan topik penelitian sekaligus juga perkembangan ilmu pengetahuan di Fakultas MIPA UGM.

\section{Trends Topik Penelitian Mahasiswa Berdasarkan Departemen}

Berdasarkan grafik 2, diketahui trends topik penelitian mahasiswa tahun 2016-2018 per departemen (Departemen Fisika, Departemen 
Kimia, Departemen Matematika, dan Departemen IKE). Berikut ini trends topik penelitian mahasiswa berdasarkan departemen yang diambil dari empat puluh besar dari seluruh topik penelitian. Untuk departemen dengan jumlah topik kurang dari empat puluh berarti topik yang kosong tersebut telah diisi dari topik di luar departemen tersebut.

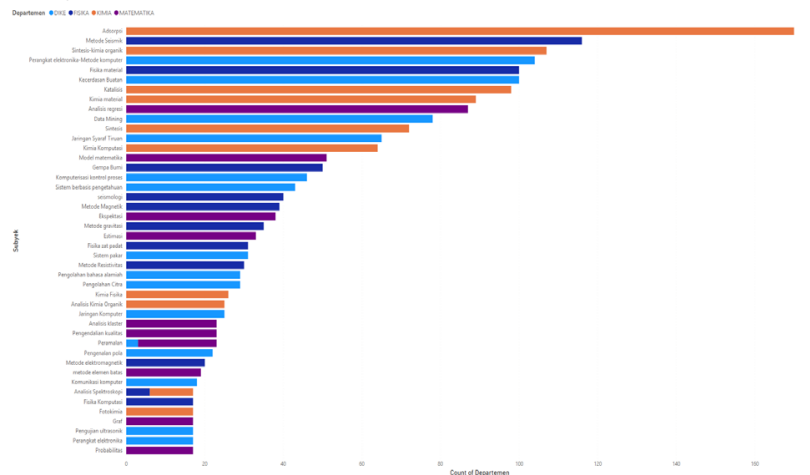

Grafik 2. Trends topik penelitian mahasiswa berdasarkan departemen

Tabel 2. Trends topik penelitian berdasarkan departemen.

\begin{tabular}{|c|l|l|l|l|}
\hline NO. & $\begin{array}{c}\text { Departemen } \\
\text { Fisika }\end{array}$ & $\begin{array}{l}\text { Departemen } \\
\text { Kimia }\end{array}$ & $\begin{array}{l}\text { Departemen } \\
\text { Matematika }\end{array}$ & $\begin{array}{l}\text { Departemen } \\
\text { IKE }\end{array}$ \\
\hline 1 & Metode seismik & Adsorpsi & $\begin{array}{l}\text { Analisis } \\
\text { regresi }\end{array}$ & $\begin{array}{l}\text { Perangkat } \\
\text { elektronika- } \\
\text { Metode } \\
\text { komputer }\end{array}$ \\
\hline 3 & Gempa bumi & Katalisis & Ekspektasi & $\begin{array}{l}\text { Data mining } \\
\text { buatan }\end{array}$ \\
\hline 4 & Seismologi & $\begin{array}{l}\text { Kimia } \\
\text { material }\end{array}$ & Estimasi & $\begin{array}{l}\text { Jaringan syaraf } \\
\text { tiruan }\end{array}$ \\
\hline 5 & $\begin{array}{l}\text { Metode } \\
\text { magnetik }\end{array}$ & Sintesis & $\begin{array}{l}\text { Analisis } \\
\text { klaster }\end{array}$ & $\begin{array}{l}\text { Komputerisasi } \\
\text { kontrol proses }\end{array}$ \\
\hline 6 & Metode gravitasi & $\begin{array}{l}\text { Kimia } \\
\text { komputasi }\end{array}$ & $\begin{array}{l}\text { Pengendalian } \\
\text { kualitas }\end{array}$ & $\begin{array}{l}\text { Sistem berbasis } \\
\text { pengetahuan }\end{array}$ \\
\hline 7 & Fisika zat padat & Kimia fisika & Peramalan & Sistem pakar \\
\hline 8 & $\begin{array}{l}\text { Metode } \\
\text { resistivitas }\end{array}$ & $\begin{array}{l}\text { Analisis kimia } \\
\text { organik }\end{array}$ & $\begin{array}{l}\text { Metode } \\
\text { elemen batas }\end{array}$ & $\begin{array}{l}\text { Pengolahan } \\
\text { bahasa alami }\end{array}$ \\
\hline 9 & $\begin{array}{l}\text { Metode } \\
\text { elektromagnetik }\end{array}$ & Fotokimia & & $\begin{array}{l}\text { Pengolahan } \\
\text { citra }\end{array}$ \\
\hline 10 & Fisika komputasi & $\begin{array}{l}\text { Analisis } \\
\text { spektroskopi }\end{array}$ & & $\begin{array}{l}\text { Jaringan } \\
\text { komputer }\end{array}$ \\
\hline 11 & $\begin{array}{l}\text { Analisis } \\
\text { spektroskopi }\end{array}$ & & $\begin{array}{l}\text { Pengenalan } \\
\text { pola }\end{array}$ \\
\hline 12 & & $\begin{array}{l}\text { Komunikasi } \\
\text { komputer }\end{array}$ \\
\hline 13 & & & Peramalan \\
\hline
\end{tabular}

Berdasarkan tabel 2, apabila dibandingkan antar departemen, topik yang paling trends adalah adsorpsi dari Departemen Kimia dengan jumlah topik tertinggi yaitu 170 topik. Topik penelitian mahasiswa dari Departemen Fisika yang paling trends adalah metode seismik. Tiga besar trend topik penelitian mahasiswa dari Departemen Fisika berturut-turutadalah metodeseismik, fisika material, dan gempa bumi. Topik penelitian Departemen Kimia yang paling trend adalah adsorpsi. Tiga besar trends topik penelitian mahasiswa dari Departemen Kimia berturut-turut adalah adsorpsi, sintesis-kimia organik, dan katalisis. Topik penelitian yang paling trends di Departemen Matematika adalah analisis regresi. Tiga besar trends topik penelitian mahasiswa dari Departemen Matematika berturut-turut adalah analisis regresi, model matematika, dan ekspektasi. Untuk Departemen IKE, topik yang paling trends adalah perangkat elektronika-metode komputer. Tiga besar trends topik penelitian mahasiswa dari Departemen IKE berturut-turut adalah perangkat elektronika-metode komputer, kecerdasan buatan dan data mining.

\section{Trends Topik Penelitian Berdasarkan Prodi}

Berdasarkan grafik 3 diketahui trends topik penelitian berdasarkan prodi yang diambil dari empat puluh besar dari keseluruhan topik penelitian mahasiswa. Berdasarkan grafik tersebut, topik yang paling trend adalah adsorpsi pada Prodi S1 Kimia dengan jumlah 114 topik

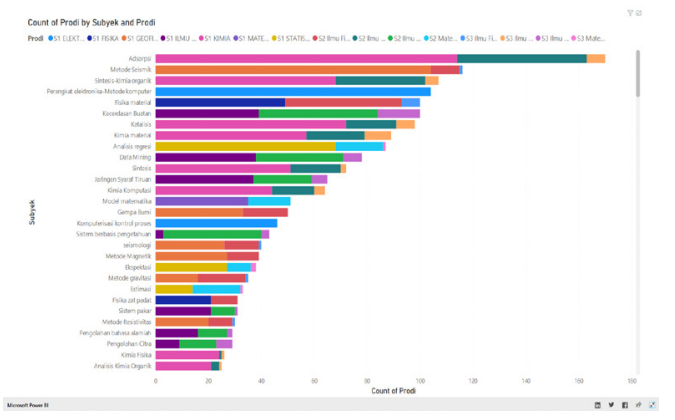

Grafik 3. Trends topik penelitian mahasiswa berdasarkan prodi

Untuk topik paling trend pada masing-masing prodi dapat dilihat pada tabel 3 berikut: 
Tabel 3. Topik paling trends pada masing-masing prodi

\begin{tabular}{|c|l|l|}
\hline No. & \multicolumn{1}{|c|}{ Prodi } & \multicolumn{1}{|c|}{ Topik Penelitian } \\
\hline 1. & S1 Elins & $\begin{array}{l}\text { Perangkat elektronika- } \\
\text { Metode komputer }\end{array}$ \\
\hline 2. & S1 Fisika & Fisika material \\
\hline 3. & S1 Geofisika & Metode seismik \\
\hline 4. & S1 Ilkom & Kecerdasan buatan \\
\hline 5. & S1 Matematika & Model matematika \\
\hline 6. & S1 Statistika & Analisis regresi \\
\hline 7. & S1 Kimia & Adsorpsi \\
\hline 8. & S2 Ilkom & Kecerdasan buatan \\
\hline 9. & S2 Ilmu Fisika & Fisika material \\
\hline 10. & S2 Ilmu Kimia & Adsorpsi \\
\hline 11. & S2 Matematika & Analisis regresi \\
\hline 12. & S3 Ilmu Fisika & Fisika material \\
\hline 13. & S3 Ilmu Kimia & Kimia material \\
\hline 14. & S3 Ilkom & Kecerdasan buatan \\
\hline 15. & S3 Matematika & Ekspektasi \\
\hline
\end{tabular}

Berdasarkan tabel 3 dapat diketahui bahwa pada Prodi S1 Fisika, S2 Fisika, dan S3 Fisika topik yang paling trend sama yaitu fisika material. Untuk S1 Ilkom, S2 Ilkom, dan S3 Ilkom topik yang paling trend juga sama yaitu kecerdasan buatan. S1 Kimia dan S2 Kimia topik yang paling trend sama yaitu adsorpsi. S1 statistika dan S2 Matematika yang paling trend juga sama yaitu analisis regresi.
Trend Topik Penelitian Berdasarkan Jenis

\section{Penelitian}

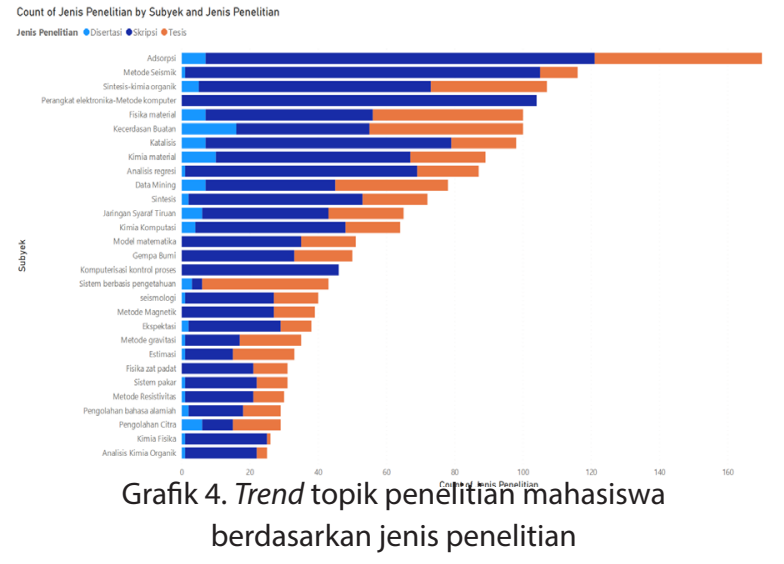

Berdasarkan grafik 4, diketahui trend topik penelitian berdasarkan jenis penelitian, yaitu skripsi, tesis, dan skripsi, yang diambil empat puluh besar dari keseluruhan topik penelitian. Berdasarkan grafik tersebut diketahui bahwa topik yang paling trend adalah adsorpsi dengan jumlah 114 pada jenis penelitian skripsi.

Tabel 4. Trend topik penelitian berdasarkan jenis penelitian

\begin{tabular}{|c|c|c|c|}
\hline NO. & Skripsi & Tesis & Disertasi \\
\hline 1 & Adsorpsi & Adsorpsi & $\begin{array}{l}\text { Kecerdasan } \\
\text { buatan }\end{array}$ \\
\hline 2 & Metode seismik & $\begin{array}{l}\text { Kecerdasan } \\
\text { buatan }\end{array}$ & Kimia material \\
\hline 3 & $\begin{array}{l}\text { Perangkat } \\
\text { elektronika- } \\
\text { Metode } \\
\text { komputer } \\
\end{array}$ & Fisika material & Adsorpsi \\
\hline 4 & Katalisis & $\begin{array}{l}\text { Sistem berbasis } \\
\text { pengetahuan }\end{array}$ & Fisika material \\
\hline 5 & $\begin{array}{l}\text { Sintesis-Kimia } \\
\text { organik }\end{array}$ & $\begin{array}{l}\text { Sintesis-Kimia } \\
\text { organik }\end{array}$ & Katalisis \\
\hline 6 & Analisis regresi & Data mining & Data mining \\
\hline 7 & Kimia material & Kimia material & $\begin{array}{l}\text { Jaringan syaraf } \\
\text { tiruan }\end{array}$ \\
\hline 8 & Sintesis & $\begin{array}{l}\text { Jaringan syaraf } \\
\text { tiruan }\end{array}$ & $\begin{array}{l}\text { Pengolahan } \\
\text { citra }\end{array}$ \\
\hline 9 & Fisika material & Katalisis & $\begin{array}{l}\text { Sintesis-Kimia } \\
\text { organik }\end{array}$ \\
\hline 10 & $\begin{array}{l}\text { Komputerisasi } \\
\text { control proses }\end{array}$ & Sintesis & $\begin{array}{l}\text { Kimia } \\
\text { komputasi }\end{array}$ \\
\hline 11 & $\begin{array}{l}\text { Kimia } \\
\text { komputasi }\end{array}$ & Analisis regresi & $\begin{array}{l}\text { Sistem } \\
\text { berbasis } \\
\text { pengetahuan }\end{array}$ \\
\hline 12 & $\begin{array}{l}\text { Kecerdasan } \\
\text { buatan }\end{array}$ & Metode gravitasi & $\begin{array}{l}\text { Pengenalan } \\
\text { pola }\end{array}$ \\
\hline 13 & Data mining & Estimasi & Sintesis \\
\hline
\end{tabular}




\begin{tabular}{|c|c|c|c|}
\hline NO. & Skripsi & Tesis & Disertasi \\
\hline 14 & $\begin{array}{l}\text { Jaringan syaraf } \\
\text { tiruan }\end{array}$ & Gempa bumi & Ekspektasi \\
\hline 15 & $\begin{array}{l}\text { Model } \\
\text { matematika }\end{array}$ & Kimia komputasi & $\begin{array}{l}\text { Pengolahan } \\
\text { bahasa alami }\end{array}$ \\
\hline 16 & Gempa bumi & $\begin{array}{l}\text { Model } \\
\text { matematika }\end{array}$ & Peramalan \\
\hline 17 & $\begin{array}{l}\text { Metode } \\
\text { magnetik }\end{array}$ & Peramalan & $\begin{array}{l}\text { Metode } \\
\text { seismik }\end{array}$ \\
\hline 18 & Ekspektasi & $\begin{array}{l}\text { Pengolahan } \\
\text { citra }\end{array}$ & Analisis regresi \\
\hline 19 & Seismologi & Seismologi & Seismologi \\
\hline 20 & Kimia fisika & $\begin{array}{l}\text { Metode } \\
\text { magnetik }\end{array}$ & $\begin{array}{l}\text { Metode } \\
\text { gravitasi }\end{array}$ \\
\hline 21 & Fisika zat padat & Metode seismik & Estimasi \\
\hline 22 & Sistem pakar & $\begin{array}{l}\text { Pengolahan } \\
\text { bahasa alami }\end{array}$ & Sistem pakar \\
\hline 23 & $\begin{array}{l}\text { Analisis kimia } \\
\text { organik }\end{array}$ & \begin{tabular}{|l} 
Jaringan \\
komputer
\end{tabular} & \begin{tabular}{|l} 
Metode \\
resistivitas
\end{tabular} \\
\hline 24 & Analisis klaster & Fisika zat padat & Kimia fisika \\
\hline 25 & $\begin{array}{l}\text { Pengendalian } \\
\text { kualitas }\end{array}$ & $\begin{array}{l}\text { Pengenalan } \\
\text { pola }\end{array}$ & $\begin{array}{l}\text { Analisis kimia } \\
\text { organik }\end{array}$ \\
\hline 26 & $\begin{array}{l}\text { Metode } \\
\text { resistivitas }\end{array}$ & Ekspektasi & Analisis klaster \\
\hline 27 & \begin{tabular}{|l|} 
Metode \\
gravitasi
\end{tabular} & Sistem pakar & $\begin{array}{l}\text { Analisis } \\
\text { spektroskopi }\end{array}$ \\
\hline 28 & $\begin{array}{l}\text { Pengolahan } \\
\text { bahasa alami }\end{array}$ & $\begin{array}{l}\text { Metode } \\
\text { resistivitas }\end{array}$ & \\
\hline 29 & Estimasi & \begin{tabular}{|l|} 
Metode \\
elektromagnetik
\end{tabular} & \\
\hline 30 & $\begin{array}{l}\text { Jaringan } \\
\text { komputer }\end{array}$ & Fotokimia & \\
\hline 31 & $\begin{array}{l}\text { Komunikasi } \\
\text { komputer }\end{array}$ & $\begin{array}{l}\text { Metode elemen } \\
\text { batas }\end{array}$ & \\
\hline 32 & $\begin{array}{l}\text { Fisika } \\
\text { komputasi }\end{array}$ & $\begin{array}{l}\text { Analisis } \\
\text { spektroskopi }\end{array}$ & \\
\hline 33 & \begin{tabular}{|l|} 
Metode \\
elektromagnetik
\end{tabular} & $\begin{array}{l}\text { Komunikasi } \\
\text { komputer }\end{array}$ & \\
\hline 34 & $\begin{array}{l}\text { Metode elemen } \\
\text { batas }\end{array}$ & Fisika komputasi & \\
\hline 35 & \begin{tabular}{|l} 
Analisis \\
spektroskopi
\end{tabular} & $\begin{array}{l}\text { Analisis kimia } \\
\text { organik }\end{array}$ & \\
\hline 36 & $\begin{array}{l}\text { Pengolahan } \\
\text { citra }\end{array}$ & $\begin{array}{l}\text { Pengendalian } \\
\text { kualitas }\end{array}$ & \\
\hline 37 & $\begin{array}{l}\text { Pengenalan } \\
\text { pola }\end{array}$ & Kimia fisika & \\
\hline 38 & Fotokimia & Analisis klaster & \\
\hline 39 & Peramalan & & \\
\hline 40 & $\begin{array}{l}\text { Sistem berbasis } \\
\text { pengetahuan }\end{array}$ & & \\
\hline
\end{tabular}

Berdasarkan tabel 4, diketahui bahwa topik penelitian yang paling trend untuk jenis skripsi dan tesis adalah adsorpsi, sedangkan untuk disertasi adalah kecerdasan buatan. Tiga besar trend topik penelitian jenis skripsi berturut-turut adalah adsorpsi, metode seismik, dan perangkat elektronika-metode komputer. Untuk jenis tesis, tiga besar trend topik penelitian berturut-turut adalah adsorpsi, kecerdasan buatan, dan fisika material. Tiga besar trend topik penelitian jenis disertasi berturut-turut adalah kecerdasan buatan, kimia materi, dan adsorpsi.

\section{Trend Topik Penelitian Berdasarkan Jenjang}

\section{Studi}

Berdasarkan grafik 5 dapat diketahui trend topik penelitian berdasarkan jenjang studi (S1, S2, dan S3) yang diambil empat puluh besar dari keseluruhan topik penelitian. Berdasarkan grafik tersebut, diketahui bahwa topik yang paling trend adalah adsorpsi yang berjumlah 114 topik pada jenjang studi $\mathrm{S} 1$.

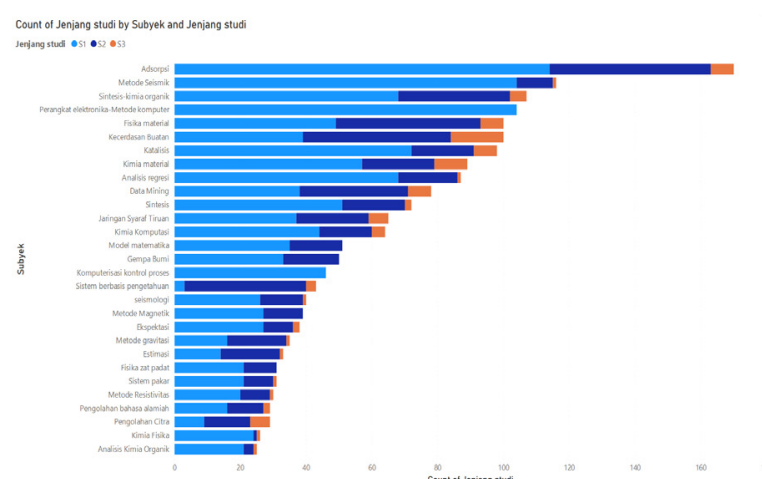

Grafik 5. Trend topik penelitian mahasiswa berdasarkan jenjang studi

Tabel 5. Trend topik penelitian berdasarkan jenjang studi

\begin{tabular}{|c|l|l|l|}
\hline No. & \multicolumn{1}{|c|}{ S1 } & \multicolumn{1}{|c|}{ S2 } & \multicolumn{1}{c|}{ S3 } \\
\hline 1 & Adsorpsi & Adsorpsi & $\begin{array}{l}\text { Kecerdasan } \\
\text { buatan }\end{array}$ \\
\hline 2 & Metode seismik & $\begin{array}{l}\text { Kecerdasan } \\
\text { buatan }\end{array}$ & Kimia material \\
\hline 3 & $\begin{array}{l}\text { Perangkat } \\
\text { elektronika- } \\
\text { Metode } \\
\text { komputer }\end{array}$ & Fisika material & Adsorpsi \\
\hline 4 & Katalisis & $\begin{array}{l}\text { Sistem berbasis } \\
\text { pengetahuan }\end{array}$ & Fisika material \\
\hline
\end{tabular}




\begin{tabular}{|c|c|c|c|}
\hline No. & S1 & S2 & S3 \\
\hline 5 & $\begin{array}{l}\text { Sintesis-Kimia } \\
\text { organik }\end{array}$ & $\begin{array}{l}\text { Sintesis-Kimia } \\
\text { organik }\end{array}$ & Katalisis \\
\hline 6 & Analisis regresi & Data mining & Data mining \\
\hline 7 & Kimia material & Kimia material & $\begin{array}{l}\text { Jaringan syaraf } \\
\text { tiruan }\end{array}$ \\
\hline 8 & Sintesis & $\begin{array}{l}\text { Jaringan syaraf } \\
\text { tiruan }\end{array}$ & $\begin{array}{l}\text { Pengolahan } \\
\text { citra }\end{array}$ \\
\hline 9 & Fisika material & Katalisis & $\begin{array}{l}\text { Sintesis-Kimia } \\
\text { organik }\end{array}$ \\
\hline 10 & $\begin{array}{l}\text { Komputerisasi } \\
\text { control proses }\end{array}$ & Sintesis & $\begin{array}{l}\text { Kimia } \\
\text { komputasi } \\
\end{array}$ \\
\hline 11 & Kimia komputasi & Analisis regresi & $\begin{array}{l}\text { Sistem berbasis } \\
\text { pengetahuan }\end{array}$ \\
\hline 12 & $\begin{array}{l}\text { Kecerdasan } \\
\text { buatan }\end{array}$ & $\begin{array}{l}\text { Metode } \\
\text { gravitasi }\end{array}$ & $\begin{array}{l}\text { Pengenalan } \\
\text { pola }\end{array}$ \\
\hline 13 & Data mining & Estimasi & Sintesis \\
\hline 14 & $\begin{array}{l}\text { Jaringan syaraf } \\
\text { tiruan }\end{array}$ & Gempa bumi & Ekspektasi \\
\hline 15 & $\begin{array}{l}\text { Model } \\
\text { matematika }\end{array}$ & $\begin{array}{l}\text { Kimia } \\
\text { komputasi }\end{array}$ & $\begin{array}{l}\text { Pengolahan } \\
\text { bahasa alami }\end{array}$ \\
\hline 16 & Gempa bumi & $\begin{array}{l}\text { Model } \\
\text { matematika }\end{array}$ & Peramalan \\
\hline 17 & $\begin{array}{l}\text { Metode } \\
\text { magnetik }\end{array}$ & Peramalan & Metode seismik \\
\hline 18 & Ekspektasi & $\begin{array}{l}\text { Pengolahan } \\
\text { citra }\end{array}$ & Analisis regresi \\
\hline 19 & Seismologi & Seismologi & Seismologi \\
\hline 20 & Kimia fisika & $\begin{array}{l}\text { Metode } \\
\text { magnetik }\end{array}$ & $\begin{array}{l}\text { Metode } \\
\text { gravitasi }\end{array}$ \\
\hline 21 & Fisika zat padat & Metode seismik & Estimasi \\
\hline 22 & Sistem pakar & $\begin{array}{l}\text { Pengolahan } \\
\text { bahasa alami }\end{array}$ & Sistem pakar \\
\hline 23 & $\begin{array}{l}\text { Analisis kimia } \\
\text { organik }\end{array}$ & $\begin{array}{l}\text { Jaringan } \\
\text { komputer }\end{array}$ & \begin{tabular}{|l|} 
Metode \\
resistivitas \\
\end{tabular} \\
\hline 24 & Analisis klaster & Fisika zat padat & Kimia fisika \\
\hline 25 & $\begin{array}{l}\text { Pengendalian } \\
\text { kualitas }\end{array}$ & $\begin{array}{l}\text { Pengenalan } \\
\text { pola }\end{array}$ & $\begin{array}{l}\text { Analisis kimia } \\
\text { organik }\end{array}$ \\
\hline 26 & $\begin{array}{l}\text { Metode } \\
\text { resistivitas }\end{array}$ & Ekspektasi & Analisis klaster \\
\hline 27 & Metode gravitasi & Sistem pakar & $\begin{array}{l}\text { Analisis } \\
\text { spektroskopi }\end{array}$ \\
\hline 28 & $\begin{array}{l}\text { Pengolahan } \\
\text { bahasa alami }\end{array}$ & $\begin{array}{l}\text { Metode } \\
\text { resistivitas }\end{array}$ & \\
\hline 29 & Estimasi & $\begin{array}{l}\text { Metode } \\
\text { elektro- } \\
\text { magnetik }\end{array}$ & \\
\hline 30 & $\begin{array}{l}\text { Jaringan } \\
\text { komputer }\end{array}$ & Fotokimia & \\
\hline 31 & $\begin{array}{l}\text { Komunikasi } \\
\text { komputer }\end{array}$ & $\begin{array}{l}\text { Metode } \\
\text { elemen batas }\end{array}$ & \\
\hline 32 & Fisika komputasi & $\begin{array}{l}\text { Analisis } \\
\text { spektroskopi }\end{array}$ & \\
\hline
\end{tabular}

\begin{tabular}{|c|l|l|l|}
\hline No. & \multicolumn{1}{|c|}{ S1 } & \multicolumn{1}{c|}{ S2 } & \multicolumn{1}{c|}{ S3 } \\
\hline 33 & $\begin{array}{l}\text { Metode } \\
\text { elektromagnetik }\end{array}$ & $\begin{array}{l}\text { Komunikasi } \\
\text { komputer }\end{array}$ & \\
\hline 34 & $\begin{array}{l}\text { Metode elemen } \\
\text { batas }\end{array}$ & $\begin{array}{l}\text { Fisika } \\
\text { komputasi }\end{array}$ & \\
\hline 35 & $\begin{array}{l}\text { Analisis } \\
\text { spektroskopi }\end{array}$ & $\begin{array}{l}\text { Analisis kimia } \\
\text { organik }\end{array}$ & \\
\hline 36 & Pengolahan citra & $\begin{array}{l}\text { Pengendalian } \\
\text { kualitas }\end{array}$ & \\
\hline 37 & Pengenalan pola & Kimia fisika & \\
\hline 38 & Fotokimia & Analisis klaster & \\
\hline 39 & Peramalan & & \\
\hline 40 & $\begin{array}{l}\text { Sistem berbasis } \\
\text { pengetahuan }\end{array}$ & & \\
\hline
\end{tabular}

Berdasarkan tabel 5, topik penelitian mahasiswa berdasarkan jenjang studi yang paling trend untuk jenjang S1 dan S2 adalah adsorpsi, untuk jenjang S3 kecerdasan buatan. Tiga besar trend topik penelitian jenjang $\mathrm{S} 1$ berturut-turut adalah adsorpsi, metode seismik, dan perangkat elektronika. Tiga besar trend topik jenjang S2 berturut-turut adalah adsorpsi, kecerdasan buatan, dan fisika material. Untuk jenjang S3, tiga besar trend topik penelitian berturut-turut adalah kecerdasan buatan, kimia material, dan adsorpsi.

Trend Topik Penelitian Berdasarkan Pembimbing

Berdasarkan grafik 6 dapat diketahui trend topik penelitian berdasarkan pembimbing pertama. Untuk mempermudah mengetahui trend topik penelitian berdasarkan pembimbing pertama, maka dalam penelitian ini juga dikelompokkan berdasarkan bidang ilmu di FMIPA UGM, yaitu bidang ilmu fisika, geofisika, ilkom, elektronika dan instrumentasi (elins), kimia, statistika, dan matematika sesuai pembimbing pertama. 


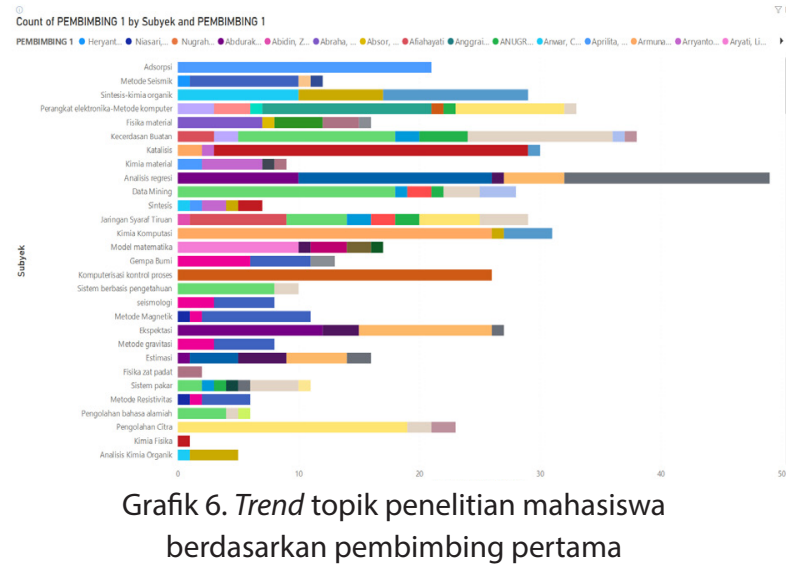

Berdasarkan hasil olah data, trend topik penelitian berdasarkan satu sampai tiga besar pembimbing pertama dan sesuai bidang ilmunya adalah tiga topik yang paling trend dengan jumlah masing-masing 26 topik yaitu bidang ilmu kimia ada dua, dengan topik katalisis, nama pembimbing pertama dengan inisial IIF dan kimia komputasi dengan pembimbing pertama RA, dan bidang elektronika dan instrumentasi dengan topik komputerisasi proses kontrol, nama pembimbing AD. Untuk topik paling trend pada masing-masing bidang studi berdasarkan pembimbing pertama adalah sebagai berikut:

\begin{tabular}{|l|l|l|l|}
\hline No. & Bidang Ilmu & \multicolumn{1}{|c|}{ Topik } & $\begin{array}{l}\text { Pembimbing } \\
\text { (Nama } \\
\text { Inisial) }\end{array}$ \\
\hline 1. & Geofisika & $\begin{array}{l}\text { 1. Metode seismik } \\
\text { 2. Metode magnetik }\end{array}$ & EH \\
\hline 2. & Kimia & $\begin{array}{l}\text { 1. Katalisis } \\
\text { 2. Kimia komputasi }\end{array}$ & $\begin{array}{l}\text { 1. IIF } \\
\text { 2. RA }\end{array}$ \\
\hline 3. & $\begin{array}{l}\text { Elektronika } \\
\text { dan }\end{array}$ & $\begin{array}{l}\text { Komputerisasi proses } \\
\text { kontrol }\end{array}$ & AD \\
\hline 4. & Fisika & Fisika material & KA \\
\hline 5. & $\begin{array}{l}\text { Imu } \\
\text { komputer }\end{array}$ & Pengolahan citra & AH \\
\hline 6. & Matematika & Model matematika & LA \\
\hline 7. & Statistika & Analisis regresi & G \\
\hline
\end{tabular}

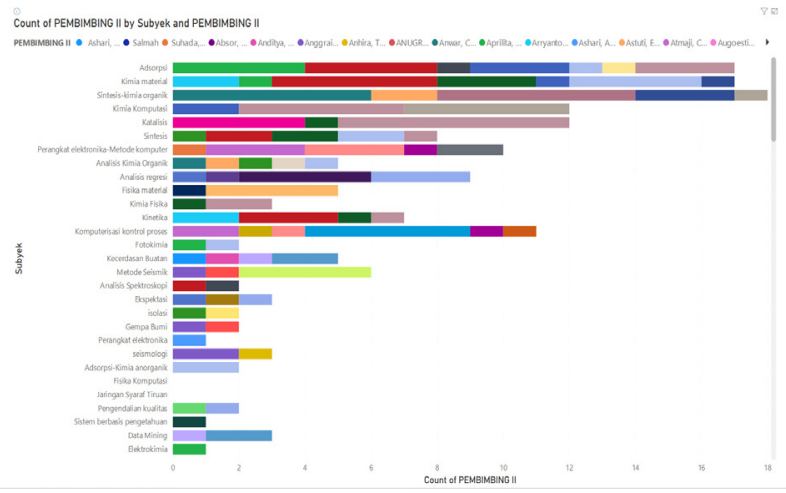

Grafik 7. Trend topik penelitian mahasiswa berdasarkan pembimbing kedua

Berdasarkan hasil penelitian di atas, diketahui topik yang paling trend adalah katalisis pada bidang ilmu kimia dengan jumlah 7 topik, nama pembimbing kedua MFP. Untuk trend topik pada masing-masing bidang studi berdasarkan pembimbing kedua adalah sebagai berikut:

\begin{tabular}{|l|l|l|l|}
\hline No. & Bidang Ilmu & \multicolumn{1}{|c|}{ Topik } & $\begin{array}{l}\text { Pembimbing } \\
\text { (Nama inisial) }\end{array}$ \\
\hline 1. & Geofisika & Metode seismik & MN \\
\hline 2. & Kimia & katalisis & MFP \\
\hline 3. & $\begin{array}{l}\text { Elektronika } \\
\text { dan } \\
\text { instrumentasi }\end{array}$ & $\begin{array}{l}\text { Komputerisasi proses } \\
\text { kontrol }\end{array}$ & AD \\
\hline 4. & Fisika & Fisika material & AK \\
\hline 5. & $\begin{array}{l}\text { Ilmu } \\
\text { komputer }\end{array}$ & $\begin{array}{l}\text { 1. Kecerdasan buatan } \\
\text { 2. Data mining }\end{array}$ & M \\
\hline 6. & Matematika & Model matematika & IE \\
\hline 7. & Statistika & Analisis regresi & WI \\
\hline
\end{tabular}

Berdasarkan olah data pada semua kategori, topik penelitian yang paling trend berdasarkan jumlah topik yang terbanyak jumlahnya pada masing-masing kategori adalah sebagai berikut:

a). Berdasarkan tahun terbit adalah adsorpsi baik pada tahun 2016, 2017, maupun 2018. Jumlah topik tentang adsorpsi yang paling banyak pada tahun 2017 dan 2018 masingmasing sama, 26 topik.

b). Berdasarkan departemen adalah adsorpsi pada Departemen Kimia dengan jumlah 170 topik.

c). Berdasarkan prodi adalah adsorpsi pada Prodi S1 Kimia dengan jumlah 114 topik 
d). Berdasarkan jenis penelitian adalah adsorpsi pada jenis penelitian skripsi dengan jumlah 114 topik

e). Berdasarkan jenjang studi juga adsorpsi pada jenjang studi S1 dengan jumlah 114 topik

f). Berdasarkan pembimbing pertama ada tiga dengan jumlah masing-masing 26 topik, yaitu katalisis dan kimia komputasi dengan pembimbing IIF dan komputerisasi proses Kontrol, pembimbing AD

g). Berdasarkan pembimbing kedua adalah katalisis, pembimbing MFP dengan jumlah topik 7.

\section{E. PENUTUP}

\section{Simpulan}

Berdasarkan hasil penelitian dapat diketahui bahwa berdasarkan jumlah topik yang diteliti mahasiswa dari masing-masing kategori maka dapat diketahui trends topik penelitian mahasiswa. Berdasarkan lima kategori yaitu jenis koleksi, jenjang studi, departemen, program studi, dan tahun terbit, jumlah topik yang paling banyak diteliti atau yang paling trends adalah topik adsorpsi dari bidang ilmu kimia. Untuk trends topik berdasarkan kategori pembimbing yang terbanyak adalah topik tentang katalisis, kimia komputasi, dan komputerisasi proses kontrol. Trends topik penelitian dari masingmasing kategori tersebut dapat sebagai acuan mahasiswa yang akan mengadakan penelitian. Bagi perpustakaan dan fakultas dapat sebagai bahan dalam menyediakan sumber-sumber referensi bagi mahasiswa.

\section{DAFTAR PUSTAKA}

Asclihati, L., Prasetyo, H. I. ., \& Prasetya, I. (2011). Metode Penelitian Sosial. Jakarta: Universitas Terbuka.

Azhari, A. (2016). Materi Pokok Teknik Penulisan Ilmiah. Jakarta: Universitas Terbuka.

Dwiyantoro. (2020). Tren Topik Penelitian Jurnal Terakreditasi Peringkat Sinta 2 Bidang Ilmu Perpustakaan Dan Informasi Di Indonesia Periode 2013-2019 (Analisis Subjek Menggunakan Pendekatan Bibliometrik Co-Word). Media Pustakawan, 27(1). Retrieved from https://ejournal.perpusnas.go.id/mp/article/ view/558

Muhiddin. (2018). Analisis Tren Penelitian Skripsi Mahasiswa Program Studi Pendidikan Matematika Kelas International di Universitas Negeri Makassar. Universitas Negeri Makasar. Retrieved from http://eprints.unm.ac.id/6365/ Pujiono, S. (2013). Terampil Menulis: Cara mudah dan Praktis dalam Menulis. Yogyakarta: Graha Ilmu. Soedojo, P. (2004). Pengantar Sejarah dan Filsafat Ilmu Pengetahuan. Yogyakarta: Gadjah Mada University Press. 